\title{
INVESTIGATION OF THERMAL PERFORMANCE OF AIR TO WATER HEAT EXCHANGER USING NANO- FLUIDS
}

\author{
NaWaf H. SAeId and Tan Heng Chia \\ Department of Mechanical, Materials \& Manufacturing Engineering, \\ The University of Nottingham Malaysia Campus, \\ Jalan Broga, 43500 Semenyih, Selangor, Malaysia. \\ nawaf.saeid@nottingham.edu.my
}

\begin{abstract}
In the present study the three-dimensional numerical simulation is selected as a tool to investigate the effectiveness of a cross flow heat exchanger. Water is selected to be mixed with nano-particles and flow inside a circular pipe while a pure air is flowing across it. Numerical simulations is carried out under laminar flow for both water and air sides. The thickness of the pipe is neglected in the present preliminary study. From the physics of the problem, the governing parameters can be determined as: the Reynolds, the type and the volume fraction of the nono-fluid. The effect of these governing parameters is studied and the results are presented. The results show significant enhancement of heat transfer with introduction of nano-particles, such as titanium-oxide (TiO2) nano-powder, compared to the pure base fluid. The accuracy of the results presented in the present study depends on the accuracy of the effective properties of the nano-fluids, which are taken from the open literature.
\end{abstract}

ABSTRAK:Dalam kajian ini, simulasi tiga dimensi berangka digunakan untuk mengkaji keberkesanan penukar haba aliran silang. Air dipilih untuk dicampurkan dengan zarah bersaiz nano dan dialirkan di dalam paip berbentuk bulat, sementara udara tulen mengalir melaluinya. Simulasi berangka dijalankan di bawah aliran lamina untuk kedua-dua belah air dan udara. Ketebalan paip diabaikan di dalam kajian permulaan ini. Dari sudut permasalahan fizik, parameter pengawal imbang boleh ditentukan sebagai: nombor Reynolds, jenis dan isipadu pecahan bendalir nano. Kesan parameter pengawal imbang ini dikaji dan keputusannya dibentangkan. Keputusan menunjukkan peningkatan pemindahan haba yang ketara dengan penggunaan zarah bersaiz nano seperti serbuk titanium oksida $\left(\mathrm{TiO}_{2}\right)$, berbanding dengan bendalir tulen. Ketepatan keputusan kajian ini bergantung kepada ketepatan sifat-sifat efektif bendalir nano yang dirujuk daripada sumber maklumat terdahulu.

KEYWORDS: heat exchanger; nanofluids; effective thermal properties

\section{INTRODUCTION}

It is well known that metals in solid form have thermal conductivities that are higher than fluids. For example, thermal conductivity of copper at room temperature is about 700 times greater than that of water. Even oxides such as alumina $\left(\mathrm{Al}_{2} \mathrm{O}_{3}\right)$, titanium oxide $\left(\mathrm{TiO}_{2}\right)$ which are good insulators compared to metals have high thermal conductivities compared to water [1]. Conventionally, when heat transfer fluids do not have the capacity to cool the mechanical 
machinery fast enough, an alternative is to use a metallic solid with several times the heat transfer capacity of the base fluid as a heat dissipating medium. In conventional cases, the suspended particles are of micrometer or even millimeter dimensions. This can give higher heat transfer rates, compared with common base fluids, but the large suspended particles in the fluid present problems such as sedimentation of particles, erosion of channel walls, fouling and increased pressure drop in the flow channel [2]. Therefore, fluids with large suspended particles have little practical application in enhancing heat heat transfer process. In comparison, nano-particles submerged in fluids (termed nanofluids) are more desirable because of their considerably smaller size, better stability and rheological properties, and higher thermal conductivities compared with microfluids, and there is no penalty in pressure drop [3]. Besides that, nanofluids are also very stable and have no additional problems, such as sedimentation, erosion, additional pressure drop and non-Newtonian behaviour due to tiny size of nanoelements and low volume fraction of nanoelements required. Investigations on adding nano-particles to the base fluid to enhance heat transfer have been carried out by many researchers [4-10] either experimentally or by numerical simulation. In these studies, they concluded that nanoparticles can remarkably enhance the thermal performance of base fluids by about $20-30 \%$. The present paper is considering the numerical simulation investigation of the thermal performance of the air to water heat exchanger in cross flow using nanofluids.

\section{MATHEMATICAL MODEL}

The mathematical model in the present study is using single phase model with the assumption that the nanofluid is single and continuous fluid phase. Parameters such as density, thermal capability, thermal conductivity and viscosity are varied in single phase flow. The governing equations are:

Conservation of mass (Continuity equation)

$$
\frac{\partial u}{\partial x}+\frac{\partial v}{\partial y}+\frac{\partial w}{\partial z}=0
$$

Conservation of momentum (Navier-Stokes equation)

$$
\begin{array}{r}
\rho_{n f}\left(u \frac{\partial u}{\partial x}+v \frac{\partial u}{\partial y}+w \frac{\partial u}{\partial z}\right)=-\frac{d p}{d x}+\mu_{n f}\left(\frac{\partial^{2} u}{\partial x^{2}}+\frac{\partial^{2} u}{\partial y^{2}}+\frac{\partial^{2} u}{\partial z^{2}}\right) \\
\rho_{n f}\left(u \frac{\partial v}{\partial x}+v \frac{\partial v}{\partial y}+w \frac{\partial v}{\partial z}\right)=-\frac{d p}{d y}+\mu_{n f}\left(\frac{\partial^{2} v}{\partial x^{2}}+\frac{\partial^{2} v}{\partial y^{2}}+\frac{\partial^{2} v}{\partial z^{2}}\right) \\
\rho_{n f}\left(u \frac{\partial w}{\partial x}+v \frac{\partial w}{\partial y}+w \frac{\partial w}{\partial z}\right)=-\frac{d p}{d z}+\mu_{n f}\left(\frac{\partial^{2} w}{\partial x^{2}}+\frac{\partial^{2} w}{\partial y^{2}}+\frac{\partial^{2} w}{\partial z^{2}}\right)
\end{array}
$$

Conservation of energy

$$
\rho_{n f} C_{p n f}\left(u \frac{\partial T}{\partial x}+v \frac{\partial T}{\partial y}+w \frac{\partial T}{\partial z}\right)=k_{n f}\left(\frac{\partial^{2} T}{\partial x^{2}}+\frac{\partial^{2} T}{\partial y^{2}}+\frac{\partial^{2} T}{\partial z^{2}}\right)
$$

where $\mathrm{u}, \mathrm{v}, \mathrm{w}\left(\mathrm{m}_{\mathrm{s}} \mathrm{s}^{-1}\right)$ are the velocity components in the $\mathrm{x}, \mathrm{y}$ and $\mathrm{z}$ direction respectively, $\rho_{\mathrm{nf}}\left(\mathrm{kg} \cdot \mathrm{m}^{-3}\right)$ is density of nanofluid, $\mu_{\mathrm{nf}}\left(\mathrm{kg} \cdot \mathrm{m}^{-1} \cdot \mathrm{s}^{-1}\right)$ is the viscosity of nanofluid, $\mathrm{p}\left(\mathrm{N} \cdot \mathrm{m}^{-2}\right)$ is 
the pressure, $\mathrm{T}(\mathrm{K})$ is temperature, $\mathrm{k}_{\mathrm{nf}}\left(\mathrm{W} \cdot \mathrm{m}^{-1} \cdot \mathrm{K}^{-1}\right)$ is the thermal conductivity of nanofluid, and $\mathrm{C}_{\mathrm{pnf}}\left(\mathrm{J} \cdot \mathrm{kg}^{-1} \cdot \mathrm{K}^{-1}\right)$ is the heat capacity of nanofluid. The properties of the nanofluid are calculated using the following equation:

$$
\begin{aligned}
& \rho_{n f}=(1-\phi) \rho_{f}+\phi \rho_{s} \\
& C_{p n f}=(1-\phi) C_{p f}+\phi C_{p s}
\end{aligned}
$$

where the subscripts $f$ and $s$ stands for fluid and soild respectively. For effective thermal conductivity, there are few conventional equationssuch as Hamilton-Crosser [4] Maxwell [4]. For viscosity, there are also some conventional equations such as Einstein's [5], Brickman [5]. He et al [7] derived the following equations for viscosity and thermal conductivity, which are adopted in the present study.

Nanofluid thermal conductivity:

$$
k_{n f}=\left(125.62 \phi^{2}+4.82 \phi+1\right) k_{f}
$$

Nanofluid viscosity:

$$
\mu_{n f}=\left(199.21 \phi^{2}+4.62 \phi+1\right) \mu_{f}
$$

where $\phi$ is in percentage of volume fraction = volume of the nano-particles/total volume, $\rho_{f}$ is the density of base fluid, $\rho_{s}$ is the density of nanoparticle, $C_{p f}$ is the heat capacity of base fluid, $C_{p s}$ is the heat capacity of nanoparticle, $k_{f}$ is the thermal conductivity of base fluid, $\mu_{f}$ is the viscosity of base fluid. The properties of the nanofluid components used in the present study are given in Table 1 [4][11].

Table 1: Properties of the $\mathrm{TiO}_{2}$ nano particles [4][11].

\begin{tabular}{|l|l|l|l|}
\hline Properties & Air & Water & TiO $_{2}$ Particles \\
\hline Density, $\rho\left(\mathrm{kg} \cdot \mathrm{m}^{-3}\right)$ & 1.03 & 997.746 & 4850 \\
\hline Specific heat Capacity, $\mathrm{C}_{\mathrm{p}}\left(\mathrm{J} \cdot \mathrm{Kg}^{-1} \cdot \mathrm{K}^{-1}\right)$ & 1009 & 4180.2 & 544.25 \\
\hline Thermal conductivity, $k\left(\mathrm{~W} \cdot \mathrm{m}^{-1} \cdot \mathrm{K}^{-1}\right)$ & 0.0241 & 0.60192 & 7.44 \\
\hline Dynamic viscosity, $\mu\left(\mathrm{kg} \cdot \mathrm{m}^{-1} \cdot \mathrm{s}^{-1}\right)$ & $1.94 \times 10^{-5}$ & $0.96172 \times 10^{-3}$ & - \\
\hline
\end{tabular}

\section{NUMERICAL METHOD AND VALIDATION TESTS}

The solution domain is considered as two regions. The inner region is the horizontal pipe with negligible thickness. The pipe is subjected to an external cross flow in a duct, which represnts the outer region. The nanofluid is flowing inside the pipe and a pure air is flowing in the duct across the pipe. The air duct is meshed by splitting the total volume into 3 volumes as shown in Fig. 1. Air duct is meshed using element of hex/wedge with copper type. For the pipe, boundary layer mesh is produced with the setting of first row at $0.01 \mathrm{~mm}$, growth factor $=1.1$, rows $=15$ with 96 mesh edge at $\theta$ direction and 28 mesh edge at radial direction. The 
face is then mesh using tri element with pave type. This is to ensure that the mesh spacing gradually increase from wall to centre of pipe. Specific continuums are created for both volumes of air and water.

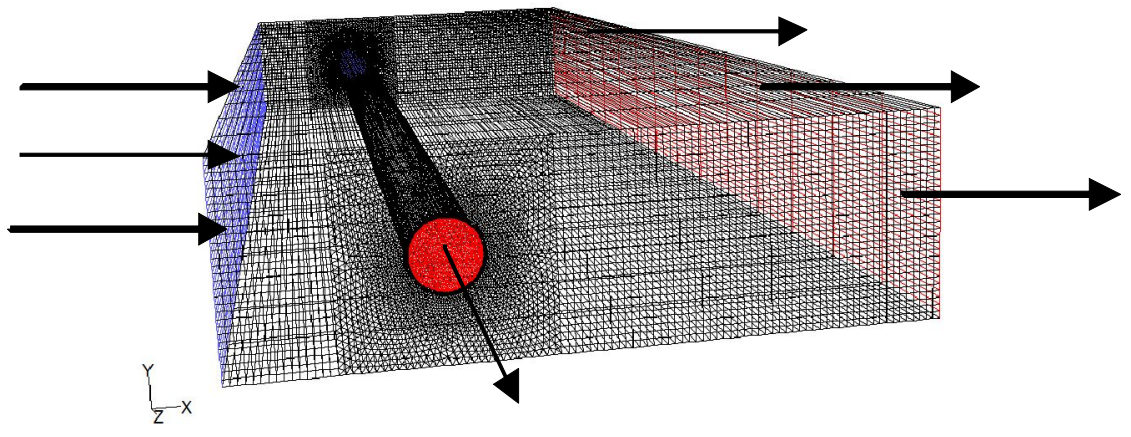

Fig. 1: Mesh geometry for internal and external domains.

Dimensions $($ Air Duct $=100 \mathrm{~mm} \times 30 \mathrm{~mm} \times 300 \mathrm{~mm}$; pipe radius $=5 \mathrm{~mm}$ and length $=300 \mathrm{~mm}$ )

Fluent 6.3 [12] is used as a tool for numerical solution of the governing equations based on finite-volume method. The governing equations were discretized using QUICK scheme for convection-diffusion formulations with SIMPLEC velocity-pressure coupling algorithm. Convergence is satisfied with a minimum residual of $10^{-5}$. Initial temperature for water is set to $293 \mathrm{~K}$ and for air it is set to $323 \mathrm{~K}$. Initial velocity for both cross flow and normal flow is calculated from the desired Re. In all the following simulations the Reynolds number for the internal and external flows is based on the pipe diameter and has the same value which is selected to be in the laminar flow regime. To test the present numerical method, the results are compared with the results of the pure water flow in pipes and external air flow across the pipe. The performance of the cross flow heat exchanger is evaluated based on the calculation of the Nusselt number, which is defined as:

$$
N u=\frac{h D}{k_{n f}}
$$

where $D$ is the diameter of the pipe, $k_{n f}$ is the thermal conductivity of the nanofluid and $h$ is the local heat transfer coefficient calculated from $h=q_{w} /\left(T_{w}-T_{a v}\right)$ where $q_{w}$ is the heat flux at the wall of the pipe, $T_{w}$ is the wall temperature and $T_{a v}$ is the average temperature across tube diameter.

The comparison of the variation of Nusselt number along the pipe with different references at $\mathrm{Re}=900$ is shown in Fig. 2a for pure water flow. For the air flow across the pipe, Fig. 2b shows the comparison of mean $\mathrm{Nu}$ around the cylinder surface with NACA [13] experiment result with $\mathrm{Re}=38900$. In this case a turbulence model is needed since the Reynolds number is high. The k-kl- $\omega$ turbulence model [12] is used to generate the results depicted in Fig. $2 \mathrm{~b}$. 


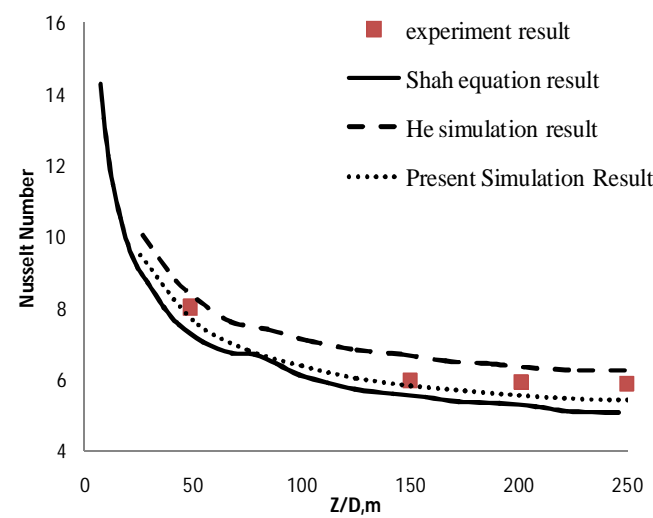

(a)

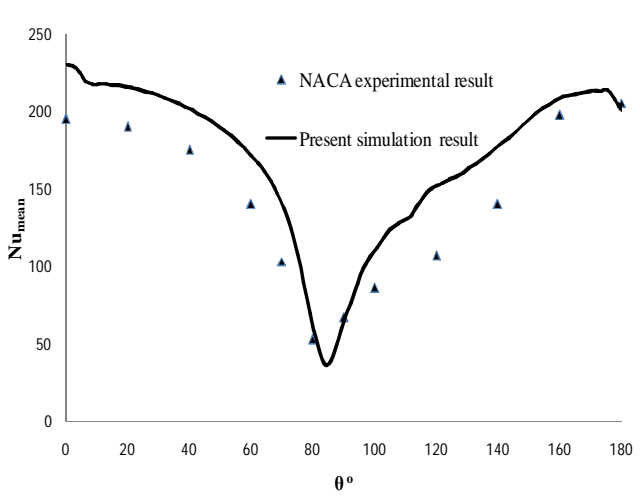

(b)

Fig. 2: (a) Variation of $\mathrm{Nu}$ along the pipe with $\mathrm{Re}=900$ for pure water [7][8], (b) Comparison of mean $\mathrm{Nu}$ around the cylinder surface with NACA [11] experiment result with $\operatorname{Re}=38900$.

In Fig. 2(a), it can be seen that the trend of simulated results with $\mathrm{Re}=900$ is almost same as the experiment result, He et al. [7] simulation and Shah's equation [8]. The present simulation results for pure water show that the Nusselt number at the end of the pipe is 5.43. The difference in the values of $\mathrm{Nu}$ between the present results and the experimental result is about $7.7 \%$. This difference in $\mathrm{Nu}$ at outlet of the pipe is about 6.63 compared with He et al [7] simulation results. Therefore, it can be conclude that the simulation is validated. The results presented in Fig. 2(b) show the accuracy of the present numerical method to predict the mean Nusselt number around the surface of the cylinder in cross flow situation compared with NACA [13] experimental results.

\section{RESULTS AND DISCUSSION}

Parametric study is carried out by varying Reynolds number of the water in the range $500,1000,1500$ and 2000 and nano-fluid volume fraction in the range of $\phi=0.6 \%, 1.5 \%, 3 \%$, $6 \%$ and 10\%. Figures 3(a) and 3(b) show the Nusselt number record highest increment at the inlet due to large temperature difference and gradually decrease and come to a constant at the fully developed region. Furthermore, from Fig 3(a), heat transfer coefficient increases as Reynolds number increase with a constant volume fraction of $\mathrm{TiO}_{2} 0.6 \%$. On the other hand, heat transfer also increase as volume fraction of $\mathrm{TiO}_{2}$ increases at constant Reynolds number $\operatorname{Re}=1000$ as shown in Fig 3(b). The increment of volume fraction from $0.6 \%-1.5 \%$ has recorded enhancement of Nusselt number at about $6.5 \%$. This happens because thermal conductivity of the nanofluid is increased from $0.62205\left(\mathrm{~W} \cdot \mathrm{m}^{-1} \cdot \mathrm{K}^{-1}\right)$ to $0.66452\left(\mathrm{~W} \cdot \mathrm{m}^{-1} \cdot \mathrm{K}^{-1}\right)$ as volume fraction increase. 


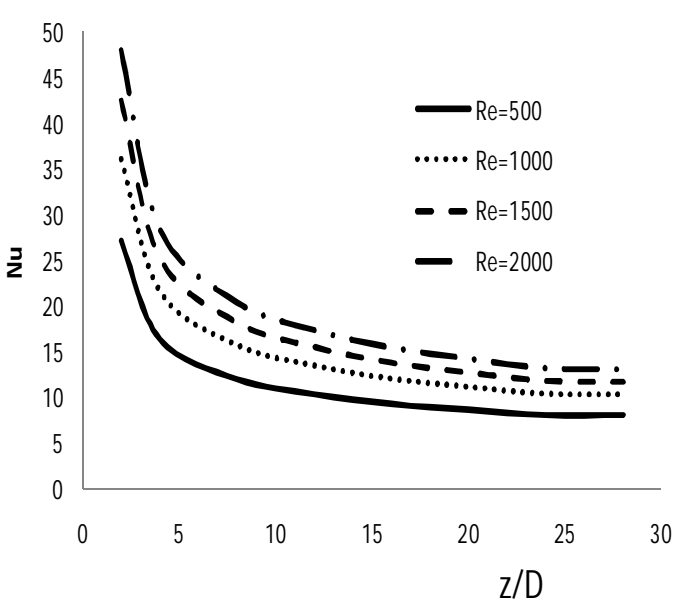

(a)

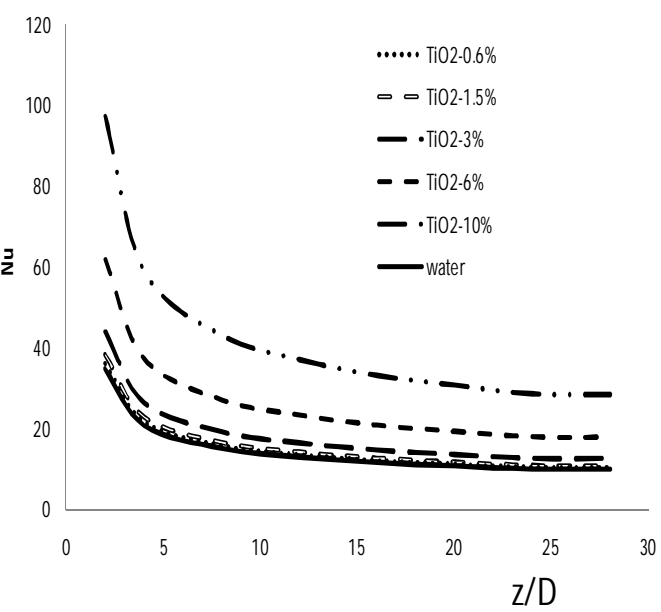

(b)

Fig. 3: Nusselt number variation along the pipe with (a) different Reynolds numbers, (b) different volume fractions of $\mathrm{TiO}_{2}$ nano-fluid at $\mathrm{Re}=1000$.

Figure 4(a) shows that the Nusselt number increases as the Reynolds number increases. The value of Nusselt number is about 139.515 at $\mathrm{Re}=2000$ which is about $49 \%$ higher than that at $\operatorname{Re}=500$. This is due to the separation happens at about $120^{\circ}$ for $\operatorname{Re}=500$ and it happens at about $98^{\circ}$ as Reynolds number increases to $\mathrm{Re}=2000$. The results presented in Fig. 4(b), shows that the Nusselt number increases as volume fraction of nano-fluid $\mathrm{TiO}_{2}$ increase. The Nusselt number for each volume fraction comes to a minimum value at angle of about $108^{\circ}$ due to separation of the flow. Beyond this angle to $180^{\circ}$, the values of the Nusselt number show slight increment. Hence, most of the heat transfer is occur between $0-100^{\circ}$.

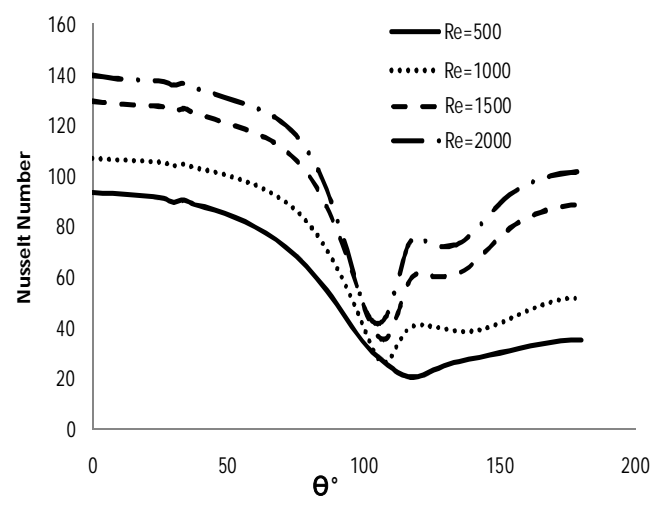

(a)

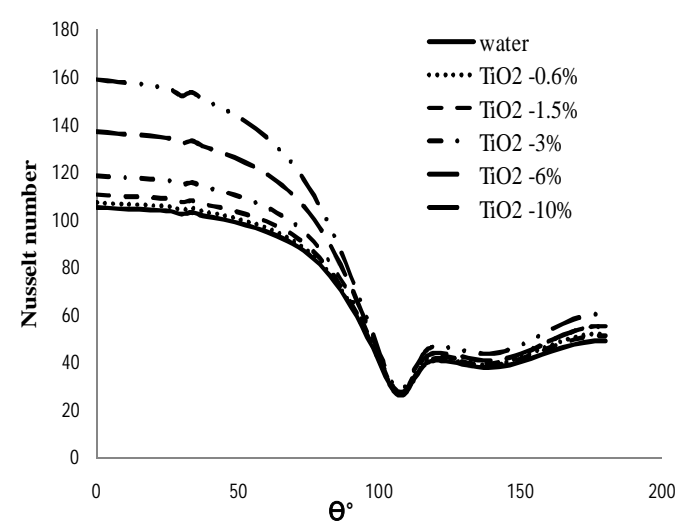

(b)

Fig. 4: Nusselt number variation at mid-span of cylinder with (a) $\mathrm{TiO}_{2}$ of volume fraction $0.6 \%$ flow at different Reynolds numbers, (b) different volume fractions of $\mathrm{TiO}_{2}$ nano-fluid at with $\operatorname{Re}=1000$.

Finally, the isotherms for both inner and outer regions are shown in Fig. 5. These results are generated for laminar cross flow of hot air over a pipe of nano-fluid $\left(0.6 \% \mathrm{TiO}_{2}-\right.$ water $)$ flow with $\mathrm{Re}=1000$. The inlet conditions are as follows: inlet water temperature $295 \mathrm{~K}$, inlet 
water velocity $0.0974 \mathrm{~m} / \mathrm{s}$, inlet air temperature $323 \mathrm{~K}$, inlet air velocity $1.8835 \mathrm{~m} / \mathrm{s}$. The isotherms for the internal pipe flow show the increase of the water temperature as the hot air flow over the pipe. On the external air side the isotherms which indicate the separation point are shown at inlet, outlet, and mid-span across the pipe.
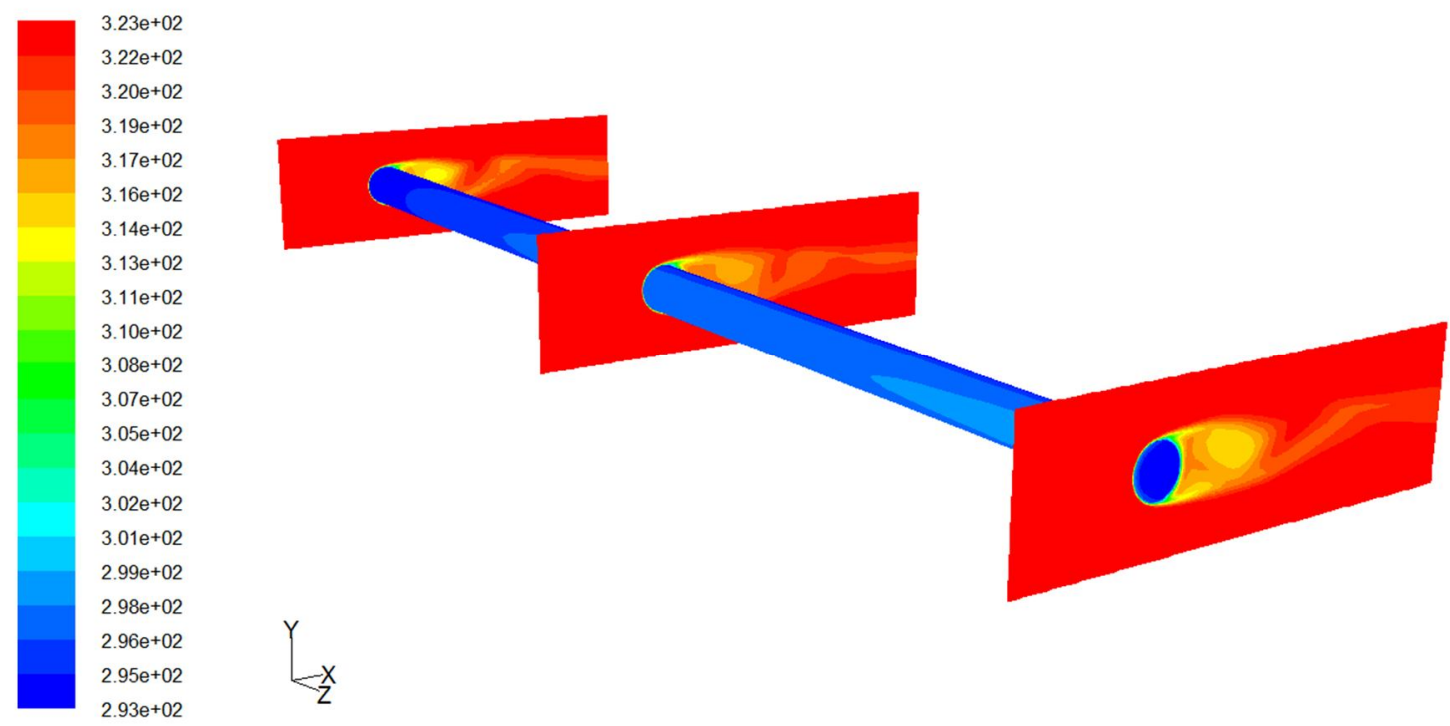

Fig. 5: Isotherms for inner and outer regions at $\mathrm{Re}=1000$ for $0.6 \% \mathrm{TiO}_{2}$ water nanofluid.

\section{CONCLUSIONS}

The present simulation results show that the convective heat transfer process can be significantly improved by introducing nano-particles such as $\mathrm{TiO}_{2}$ in base fluid. The present simulation results show the enhancement in the convection heat transfer by either increase the Reynolds number or the nano-particles volume fraction. However, higher volume fraction will cause higher wall shear stress which may need more energy to pump the nano-fluid in the cylindrical pipe and also may cause abrasion of the cylinder wall which causes corrosion, scaling, and clogging of the pipe. The accuracy of the present results depends on the accuracy of the effective properties of the nano-fluids, which are taken from the open literature.

\section{REFERENCES}

[1] S. Lee, S. Li, S. Choi "Measuring Thermal Conductivity of fluids containing oxide nanoparticles". ASME J. Heat Transfer, vol. 121, 280-289, 1999.

[2] V. Trisaksri and S. Wongsies "Critical Review of Heat Transfer Characteristics of Nanofluids". Renewable and Sustainable Energy Review, vol. 11, 512-523, 2007.

[3] W. Daungthongsuk and S. Wongwises "A Critical Review of Convective Heat Transfer of Nanofluids". Renewable and Sustainable Energy Review, vol. 11, 797-817, 2007.

[4] Y. Xuan and Q. Li "Heat transfer enhancement of nanofluids". Int. J. Heat Fluid flow, vol. 21, 58-64, 2000.

[5] C.T.Nguyen, G.Roy, C. Gauthier, N. Galanis "Heat transfer enhancement using $\mathrm{Al}_{2} \mathrm{O}_{3}$-water nanofluid for an electronic liquid cooling system". Applied thermal enginnering, vol. 27, 15011506, 2007. 
[6] D.S. Wen and Y.L. Ding "experiment investigation into convective heat transfer of nanofluids at the entrance region under laminar flow conditions". Int. J. Heat and Mass transfer, vol. 47, 5281-5288, 2004.

[7] Y. He, Y. Men, Y. Zhao, H. Lu, Y. Ding "Numerical investigation into the convective heat transfer of $\mathrm{TiO} 2$ nanofluids flowing through a straight tube under the laminar conditions". Applied thermal Engineering, vol. 29,1965-1972, 2009.

[8] R.K. Shah "Thermal entry length solutions for the circular tube and parallel plates". in: Proceedings of the 3rd National Heat and Mass Transfer Conference, Indian Institute of Technology, Bombay, I (Paper HMT-11-75), 1975.

[9] C.T.Nguyen,F.Des, N.Galanis, G. Roy, T. Mare, S. Boucher, H.A.Mintsa, "Viscosity data for $\mathrm{Al}_{2} \mathrm{O}_{3}$ - water nanofluid- hysteresis: is the heat transfer enhancement using nanofluids reliable?". International Journal of thermal Sciences vol. 47, 103-111, 2008.

[10] Z.W.Ding,S.C.Cheah,N. H.Saeid, "Parametric study of heat transfer enhancement using nanofluids". Proceedings of ICEE 2009 3rd International Conference on Energy and Environment, 7-8 December 2009, Malacca, Malaysia, pp. 348-352, 2009.

[11] F.P. Incropera, and D.P. Dewitt, "Fundamentals of Heat and Mass Transfer", 6th edition, WILEY.(2006).

[12] FLUENT 6.0 Documentation.

[13] E.Schmidt and K.Venner "Heat Transfer Over The Circumference Of a Heated Cylinder in Transverse Flow“. Techical Memorandum no 1050, NACA, 1941. 